\title{
Granica dirzew.
O leśnych doświadczeniach granicznych w opowiadaniu An der Baumgrenze Thomasa Bernharda
}

\begin{abstract}
Wszystkie twarze mieniły się czerwonawo od różowego ognia zorzy. Już pokazały się gwiazdy. Przy drodze zdarzyła się akurat gospoda. Wszedłem do niej ${ }^{1}$.
\end{abstract}

Niezwykłość dzieła Thomasa Bernharda nieprzerwanie związana jest z przekraczaniem granic lub zatrzymywaniem się tuż przed nimi. Intensywność i dotkliwość zawartej w tych tekstach tematyki choroby, szaleństwa, niemożności osiągnięcia celu czy trudnych relacji z rodziną i ojczyzną, w połączeniu z wypowiedziami austriackiego pisarza na temat opisywania krajobrazu w jego tradycyjnym rozumieniu ${ }^{2}$, skłania do odsuwania topograficznego doświadczania granicy na dalszy plan. Utwory Bernharda zakorzenione są w klimacie i krajobrazie górzystej Austrii, wraz z jej piętrowością terenu i dużą powierzchnią lasów, jednak długie, szkatułkowo złożone zdania nie mieszczą w sobie tego, co jest jedynie uspokajającym: tu jesteś, czytelniku. Bernhard decydował się na całkowite pomijanie tego,

* Uniwersytet im. Adama Mickiewicza w Poznaniu, Wydział Filologii Polskiej i Klasycznej, Instytut Filologii Polskiej, Zakład Badań nad Tradycją Europejską, e-mail: kasiaszym93@op.pl.

${ }^{1}$ R. Walser, Spacer (I), [w:] tegoż, Mały krajobraz ze śniegiem. Małe poematy. Utwory proza. Mała proza, przeł. M. Łukasiewicz, Izabelin 2003, s. 141.

Spaziergang Walsera kończy się w miejscu, w którym zaczyna się An der Baumgrenze Bernharda. Wybierają oni jednak inne słowa, z których jedno ma w sobie cząstkę nazywającą tego, który przyjmuje podróżnych, a drugie tego, który przybywa - Walser das Wirtshaus ('gospoda'), a Bernhard das Gasthaus ('gościniec').

${ }^{2}$ Zob. T. Bernhard, Spotkanie. Rozmowy z Krista Fleischmann, przeł. S. Lisiecka, Warszawa 2010, s. 12. 
co wie zarówno pisarz, jak i odbiorca ${ }^{3}$, będąc przekonanym, że jedynie „to, czego nikt nie widzi, jest warte spisania" ${ }^{4}$. Radykalizm autora Wymazywania powodowany był tym, iż wszystko w jego życiu i twórczości musiało się zgadzać. Nie uznawał możliwości pójścia na kompromis i nie mógł na niego przystać, zdając sobie sprawę z ważności tego, co chciał powiedzieć. Swój umysł i sposób patrzenia wytężał do granic możliwości. Jednocześnie jego literacka surowość spotykała się ze szczególnym rodzajem duchowości, podobnie jak w utworach największych geniuszy muzyki. Szczególne wyczulenie na materię języka i świata odbija się między innymi w intensywności i powtarzalności, w różnych kontekstach, pewnych słów lub wyrażeń, które pisarz włączył do swojego własnego uniwersum pojęć, nie czyniąc $\mathrm{z}$ nich przy tym czegoś nienaturalnego czy wynaturzonego. $\mathrm{O}$ ważności słów drzewno-leśnych oraz tych, które są z nimi spokrewnione, świadczy znaczna część twórczości Thomasa Bernharda, zarówno prozatorskiej, jak i poetyckiej oraz dramatycznej ${ }^{5}$.

Każda styczność bohaterów Bernharda z wybranym elementem rzeczywistości jest niezwykle intensywna. Nie istnieją u niego przypadkowe domy czy lasy, a nawet drobniejsze elementy, takie jak fotel. Każde zetknięcie z materią świata powoduje jakąś reakcję (fizyczną lub myślową). Przepełniona przestrzeń nie dawałaby bowiem miejsca na myśli lub spowalniałaby je. Tym ważniejszy jest zatem wybór każdego fragmentu natury, ubioru, miejsca zamieszkania i przedmiotów tam się znajdujących. Scenografia, która towarzyszy procesowi myślowemu, jest niezwykle oszczędna, jakby umysł, skupiony na procesach wewnętrznych, odbierał tylko te najbardziej podstawowe i jednocześnie najbardziej intensywne elementy świata. Niektóre przestrzenie silniej też współdziałają z naturą bohatera, uzewnętrzniają jego osobowość. Jednym $\mathrm{z}$ takich miejsc jest las, wprowadzający czytelnika jeszcze głębiej w umysł bohatera. Obszar ten może funkcjonować podobnie jak granica, która - na co wskazywał już Georg Simmel, niemiecko-żydowski filozof i socjolog - „nie jest «faktem przestrzennym», który rodzi efekty społeczne i kulturowe, lecz odwrotnie, jest faktem społecznym i kulturowym, który tylko formuje się przestrzennie" ${ }^{\prime 6}$. Jednocześnie graniczne są poszczególne formy istnienia zarówno niektórych pojedynczych drzew, jak i lasu, który - sam będąc granicą - mieścić ją może także w sobie.

${ }^{3}$ Zob. Die Ursache bin ich selbst (Madryt 1986, Przyczyna jestem ja sam).

4 "Das, was niemand sieht, das hat einen Sinn, aufzuschreiben". Tamże.

${ }^{5}$ Opisane lub jedynie zasygnalizowane w tym artykule miejsca leśno-drzewne w twórczości Thomasa Bernharda były tematem mojej pracy magisterskiej pt. "Der Wald ist groß, die Finsternis auch". Thomas Bernhard o doświadczeniach granicznych (leśnych, drzewnych), napisanej pod opieką prof. Katarzyny Kuczyńskiej-Koschany w Instytucie Filologii Polskiej UAM i obronionej 1 września 2017 roku.

${ }^{6}$ Cyt. za: M. Szulakiewicz, Granice jako problem wspótczesnej kultury - wprowadzenie, [w:] Granice i ograniczenia. O doświadczeniu granic i ich przekraczaniu, red. M. Szulakiewicz, Toruń 2010, s. 7-17, tu: 8 . 
Jak podaje Agata Wittchen-Barełkowska w notatce dotyczącej Oddechu (1978), czyli jednej z części składających się na Autobiografie, zachowanej w Archiwum Thomasa Bernharda w Gmunden w Górnej Austrii, autor pisze o swoim tekście jako dokumencie przedstawiającym „stan egzystencji młodego człowieka" ${ }^{7}$, który zostaje wyrwany z dotychczasowego życia przez groźną chorobę i doprowadzony do Lebensgrenze:

Zewnętrzne i wewnętrzne procesy, nieustannie odnoszące się do siebie nawzajem $\mathrm{w}$ tym procesie rozwoju choroby, rozciągającym się od połowy stycznia do końca sierpnia 1949, są treścią niniejszej książki, która jest jednocześnie przerażająca i rozjaśniająca pewne kwestie. Prastare salzburskie szpitale stanowią w niej tło dla tego dokumentu o niespokojnej, przerażającej w swoich podstawowych założeniach (wątpliwościach?), a jednak w swoim mechanizmie oświecenia produktywnej młodości, podczas której bohater bardzo często i bardzo intensywnie dochodził do najbardziej skrajnej granicy życia. Dokładnie na tej granicy, tak jest tu napisane, wyłączając swój rozum, w łazience szpitala w Salzburgu, dzielonej z innym chorym, a później umierającym i ostatecznie zmarłym, w najważniejszym dlań momencie podjął decyzję, by żyć nie tym życiem, ale swoim własnym ${ }^{8}$.

Podobnie pisze Bernhard we fragmencie Moich nagród mówiącym o odznaczeniu honorowym Koła Kultury Federalnego Związku Przemysłowców Niemieckich:

Latem tysiąc dziewięćset sześćdziesiątego siódmego roku przez trzy miesiące przebywałem w wiedeńskim Szpitalu Chorób Płuc Am Steinhof - sąsiadującym wówczas, dziś zresztą też, z Zakładem dla Obłąkanych - w pawilonie Hermann, w którym w każdym z siedmiu pokojów leżało po dwóch, trzech pacjentów i wszyscy Ci pacjenci jeszcze w czasie mojego pobytu zmarli, z wyjątkiem studenta teologii i mnie. Jeśli o tym wspominam, to tylko dlatego, że bez tych wyjaśnień nie sposób byłoby zrozumieć tego, co nastąpiło. Podobnie jak tyle razy w przeszłości, znowu

\footnotetext{
${ }^{7}$ Przy opisie tekstów pochodzących z Archiwum Thomasa Bernharda w Gmunden w Górnej Austrii autorka posługuje się stosowanymi tam oznaczeniami; w tym przypadku jest to NLTB W 12/1. A. Wittchen-Barełkowska, Kategoria teatralności w dziele Thomasa Bernharda, Poznań 2014, s. 130.

${ }^{8}$ Tamże. Barełkowska pisze też o „granicach przedstawienia”, do których posuwają się niektórzy bohaterowie Bernharda, w kontekście "akcji performatywnych artystów balansujących na granicy autodestrukcji i zagrożenia życia" (tamże, s. 190). Autorka podaje przykład narratora Wymazywania, który w pełni urzeczywistnia akt wymazywania - ostatnie zdanie powieści może świadczyć bowiem o jego samobójstwie. „Franz niszczy historię, której sam również jest częścią, dlatego jej ostateczne wymazanie równoznaczne jest z unicestwieniem siebie samego" (tamże).
} 
zostałem zepchnięty na skraj egzystencji [„, an die Grenze meiner Existenzmöglichkeit"] i zostawiony na lodzie przez lekarzy9.

W roku 1967 po raz pierwszy ukazuje się, na łamach czasopisma "Jahresringe" 1967/68, opowiadanie An der Baumgrenze ${ }^{10}$, które dwa lata później (marzec 1969) znajdzie się w zbiorze o tym samym tytule, wraz z Der Kulterer ${ }^{11}$ i Der Italiener. Tom ten został wydany razem z dwunastoma rysunkami Antona Lehmdena - austriackiego malarza i grafika należącego do Wiedeńskiej Szkoły Realizmu Fantastycznego ${ }^{12}$, „cyzelatora natury z delikatną kreską"13, do którego, piętnaście lat później, literacko odwoła się Bernhard w Wycince, zmieniając jego nazwisko na Rehmden - przez Der Residenz Verlag (An der Baumgrenze. Erzählungen. Zeichnungen Anton Lehmden), co doprowadziło do drobnego konfliktu między pisarzem a jego stałym wydawcą Siegfriedem Unseldem $^{14}$ (Suhrkamp und Insel Verlag). Te trzy małe prozy Bernhard poprzedził mottem, które stanowi zdanie z tekstu szwajcarskiego pisarza Roberta Walsera pt. Spacer (I): „Das Land war wie versunken in ein tiefes, musikalisches

${ }^{9}$ T. Bernhard, Moje nagrody, przeł. M. Kędzierski, Warszawa 2010, s. 18.

${ }^{10}$ Tytuł polskiego tłumaczenia brzmi Na granicy lasów, przyjmuję jednak brzmienie oryginalne ze względu na różnice pomiędzy, znanym w leśnictwie, terminem "granica drzew" a wyrażeniem "granica lasów", które bardziej kojarzy się z granicą oddzielającą dwa lasy.

${ }^{11}$ W 2011 roku, nakładem Insel Verlag, opowiadanie to zostało wydane osobno wraz z dwunastoma rysunkami Petera Herzoga oraz posłowiem Raimunda Fallingera.

${ }^{12}$ Aneta Grodecka w szkicu Fotografie nieistniejacego świata. O polskiej sztuce fantastycznej pisze o „wirtuozerskim warsztacie” przedstawicieli realizmu fantastycznego i cytuje fragment książki Jerzego Madeyskiego: „Realizm fantastyczny operuje nienagannym, znanym od starożytności warsztatem sztuki iluzjonistycznej, choć równie często sięga po warsztat florenckiego zwłaszcza quattrocenta, $\mathrm{z}$ jego delikatnym, acz wyrazistym i definiującym kształty rysunkiem i jasnym, pogodnym kolorytem". J. Madeyski, Realizm fantastyczny, [w:] Malarze polscy XIX i XX wieku. Mała encyklopedia rynku sztuki, red. J. Rapicka, Kraków 2004, s. 188-189. Cyt. za: A. Grodecka, Fotografie nieistniejącego świata. O polskiej sztuce fantastycznej, „Poznańskie Studia Polonistyczne. Seria Literacka", nr 28 (48), s. 62.

${ }^{13}$ T. Bernhard, Wycinka. Ekscytacja, przeł. M. Muskała, Warszawa 2011, s. 154.

${ }^{14}$ Bernhard napomknął Unseldowi o planowanej publikacji w liście z 12 stycznia 1969 (T. Bernhard, S. Unseld, Der Briefwechsel, Frankfurt nad Menem 2011, s. 97), pisząc iż dał pewnemu staremu przyjacielowi z Wiednia trzy krótkie prozy do bibliofilskiego tomu jego rysunków. Sugerował w ten sposób, że jest to głównie książka Lehmdena, a jego własne drobne teksty jedynie towarzyszą grafikom artysty, chcąc tym samym złagodzić reakcję swojego stałego wydawcy. W odpowiedzi na ten list Unseld nie odnosi się ani słowem do wiadomości o publikacji An der Baumgrenze w obcym wydawnictwie. Informuje o tym w tekście dla „Die Presse" obecny redaktor naczelny wydawnictw Suhrkamp i Insel, pisząc jednoczenie, iż powstanie tego tomu najpewniej nie było podyktowane jedynie względami ekonomicznymi. Raimund Fellinger wspomina o powinowactwach między malarstwem Lehmdena a prozą Bernharda, do których zalicza „antyidylliczność" (lub „zaburzoną idyllę"), krajobrazy przekształcone, noszące w sobie ślad wojny, ale podkreśla też, że tym, co różnicuje obie twórczości, jest iskra nadziei obecna w rysunkach Lehmdena i dopełniająca teksty Bernharda. Drugą wspólną cechą jest dążenie do sztuczności (die Künstlichkeit), brak naśladowania naturalnych struktur, a zamiast nich tworzenie nowych - takich, które prowadzą własny żywot na całkowicie zaciemnionej scenie, jak pisał Bernhard. R. Fellinger, Der herzliche Thomas Bernhard, [online] http://diepresse.com/home/spectrum/zeichenderzeit/565184/print.do (dostęp: 10.03.2018). 
Denken"15. Walser umarł na atak serca podczas jednego z samotnych spacerów, „schodząc ze stromego ośnieżonego zbocza"16. Wcześniej przez wiele lat przebywał w zakładzie dla umysłowo chorych, o leśnej nazwie Waldau, a w roku 1933 został przeniesiony do ośrodka w Herisau, w którym spędził ostanie dwadzieścia trzy lata swojego życia, nie kontynuując już twórczości literackiej. Tak pisał w 1944 do Carla Seeliga, swojego wydawcy, a wówczas także formalnego opiekuna i towarzysza ostatnich przechadzek: „Mój świat został zniszczony przez nazistów. Gazety, do których pisałem, przepadły; ich redaktorzy zostali przepędzeni albo umarli. $\mathrm{W}$ tej sytuacji stałem się prawie skamieliną"17.

Wiele łączy tych dwóch pisarzy. Między innymi filozofia choroby czy traktowanie własnej twórczości, $\mathrm{w}$ znacznej mierze drobnych form prozatorskich, jako fragmentów spójnej całości, w której krążą powtarzające się motywy i tematy, a wśród nich jeden z najważniejszych - spacer - traktowany również jako forma narracyjna ${ }^{18}$. Bo przecież pisanie jest jak spacer.

Akcja An der Baumgrenze rozgrywa się w gospodzie ${ }^{19}$, w małej, wysoko położonej miejscowości Mühlbach. Narrator, pracownik żandarmerii, obserwuje dziewczynę i młodego mężczyznę - rolnika - którzy właśnie wynajęli pokój. W swoich spostrzeżeniach podkreśla dziwność pojawienia się pary późnym wieczorem, szczególnie o tej porze roku, wprowadzając tym samym nastrój tajemniczości - trochę kryminalnej, a trochę magiczno-baśniowej. W tym samym czasie, siedząc w jadalni, pisze list do narzeczonej, dla której przygotowuje miejsce $w$ Mühlbach. Wspomina o jej lęku przed tym miejscem, mówi tė̇, iż „Jej stan zmienił się w sposób na tyle chorobliwy, iż lęka się teraz wszystkiego"20. Sam również ma świadomość, że to górskie odludzie

${ }^{15}$ Zdanie to w polskim przekładzie utworu Walsera brzmi: „Jakby się pogrążała w głębokiej, śpiewnej zadumie". R. Walser, Spacer (I), s. 141.

${ }^{16}$ M. Łukasiewicz, Robert Walser, Warszawa 1990, s. 19.

${ }^{17}$ Tamże, s. 16-17.

${ }^{18}$ Por. Z. Bauer, Wędrować, żeglować, wertować: o pewnych wspótczesnych metaforach podróży, "Annales Universitatis Paedagogicae Cracoviensis. Studia Historicolitteraria" 2007, nr 7, s. 35-44. C. Albes, Der Spaziergang als Erzählmodell. Studien zu Jean-Jacques Rousseau, Adalbert Stifter, Robert Walser und Thomas Bernhard, Túbingen, Bazylea 1999.

${ }^{19}$ To z założenia tymczasowe miejsce niejednokrotnie oznacza w tekstach Bernharda miejsce ostatnie. W Mrozie czytamy: „Gospoda jest jedną z tych, w których nocuje się tylko z konieczności, jeden jedyny raz" i fragment dalej: „- W tej gospodzie nigdy nie przyszła mu do głowy tak zwana «budująca» myśl. Takie myśli wprawdzie są mu obce z natury, nieprzyzwoitością jest już sama chęć zbliżenia się do nich. Toteż on je odstręcza. - Człowiek sam określa rodzaj myśli, jakie chce mieć. - Zdumiewające, «jak nieprzychylne bywa często to, do czego podchodzi się z ufnością». Życie w gospodzie leży «na linii wszystkich wielkich mąk», których on przecież szuka. W zadawaniu sobie bólu ćwiczył się już od dziecka. - Z początku sprawdzałem siebie. Potem nabrałem zapału. - Z biegiem lat doszedł w tym do granic obłędu. - Gospoda jest koniec końców koronnym świadkiem moich uczuć, moich stanów. «To jestem ja», mówi wszystko... nie ma już cnoty, nie ma skromności, jest tylko spotęgowana w sobie ponad wszelką miarę nieczystość". T. Bernhard, Mróz, przeł. S. Błaut, posł. H. Orłowski, Poznań 1979, s. 24-25.

${ }^{20}$ T. Bernhard, Na granicy lasów, przeł. S. Lisiecka, [w:] Czyż jest piękniejszy kraj... Opowiadania austriackie, oprac. S.H. Kaszyński, Warszawa 1980, s. 168-178, tu: 169. Przy kolejnych 
"rujnuje nerwy" (s. 173) i dla nich obojga jest „karą śmierci” (s. 170), przed którą ratuje jedynie „zejście w dolinę, a więc do ludzi, do cywilizacji” (s. 170). Podobnie przestrzeń ta oddziaływała na żonę inspektora przebywającą teraz w sanatorium przeciwgrú́liczym w Grabenhof, którą Mühlbach doprowadziło do śmiertelnej choroby płuc. Małe miejscowości są karą - a nawet karą śmierci - dla ludzi pochodzących z dużych miast. Narrator dostrzega też podobieństwa pomiędzy jego relacją z narzeczoną a dwojgiem obserwowanych ludzi. Zapożyczając słowa nieznanej dziewczyny, mówi o jej „sytuacji bez wyjścia”, , ucieczce w naukowe (prawnicze?) lektury”, „, brutalności stosowanej”, wywołującym lęk podobieństwie mężczyzny do ojca; słyszy też o ",poronieniu i przekazie pieniężnym".

„Droga obojga do szkoły wiodła przez mroczny las, którego się bali, pamiętali zbiega z Göllersdorf w ubraniu więziennym. Przewrócił się w lesie o pień drzewa i wykrwawił z powodu głębokiej rany głowy, został nadgryziony przez lisy i oni go znaleźli" (s. 172). Podobny fragment znajdzie się później w Korekcie ${ }^{21}$ :

[...] nasza droga do szkoły wcale nie była najłatwiejsza, powiedziałem, po pierwsze bowiem $\mathrm{w}$ drodze do tej szkoły baliśmy się, ponieważ była to droga całkiem niebezpieczna, na całym odcinku wiodła przez las i skały wzdłuż Aurach, wszędzie na tej drodze do szkoły czaiły się niebezpieczeństwa i przeważnie cały czas na tej drodze czegoś się lękaliśmy, tę naszą drogę do szkoty określałem mianem drogi życia, nasza droga do szkoły była bowiem całkowicie, wraz ze wszystkim, co ją charakteryzowało, ze wszystkimi zdarzeniami, możliwościami tudzież niemożliwościami, całkowicie porównywalna z moją drogą życia i prawdopodobnie także z drogą życia Höllera, nasza droga życia była bowiem równie niebezpieczna, na niej też musieliśmy się wciąż czegoś lękać, ze wszystkim, co ją charakteryzowało, wszystkimi zdarzeniami, możliwościami tudzież niemożliwościami, była taką drogą, którą musieliśmy dzień w dzień chodzić przez las i skały, powiedziałem, moje dzieciństwo zawsze łączę z tą drogą do szkoły, i nic w dzieciństwie nie istnieje dla mnie, powiedziałem, bez tej drogi do szkoły, na której zebraliśmy tyle doświadczeń, które potem ciągle się powtarzały, wszystko, co przydarzyło nam się potem, w jakiś sposób przydarzyło się nam już na tej drodze, z tym lękiem, który często nawiedza nas dzisiaj, chodziliśmy już po naszej drodze do szkoły ${ }^{22}$.

Bernhard w swoich tekstach wykorzystuje - zakorzenione w literaturze i sztuce - podwójne nacechowanie lasu, który sprzyja ascetycznemu skupieniu, ale też chorobliwemu natężeniu myśli. Jak podaje leksykon Coopera,

przytoczeniach fragmentów tego opowiadania, numery stron podaję w nawiasie, bezpośrednio po cytacie.

${ }^{21}$ Analogiczne jest także noszenie drewna do ogrzania szkoły lub pokoju w gospodzie.

${ }^{22}$ T. Bernhard, Korekta, przeł. M. Kędzierski, Warszawa 2013, s. 123. 
jest to „miejsce próby i inicjacji, miejsce mroczne i pełne nieznanych niebezpieczeńst $w^{\prime \prime 2}$. Niektóre przestrzenie $\mathrm{w}$ tekstach austriackiego pisarza silniej współdziałają z umysłem bohatera, a las jest z pewnością jedną z nich, umieszczając nas tym samym jeszcze głębiej w zapisie myśli czy emocji. Stan natury odpowiada tu bowiem stanowi człowieka, i odwrotnie.

Narrator, mimo braku racjonalnych przesłanek, ma przypuszczenia co do tego, iż nowi goście w jakiś sposób „naruszają prawo" (s. 173), co znajdzie później swoje potwierdzenie w ich pokrewieństwie. An der Baumgrenze to nie jedyny tekst Bernharda, w którym występuje relacja o podłożu kazirodczym. W niektórych utworach można się jej jedynie domyślać, w innych natomiast autor pisze o niej wprost ${ }^{24}$. Relacja ta jest podstawą takich tekstów, jak Korekta czy Kalkwerk, w którym żona głównego bohatera jest jednocześnie jego przyrodnią siostrąa ${ }^{25}$. Najczęściej kończy się owa relacja śmiercią (różnie motywowaną) jednego bądź obojga bohaterów. W An der Baumgrenze dziewczyna popełnia samobójstwo poprzez zatrucie lekami, a jej brat zostaje znaleziony zamarznięty tuż poniżej granicy drzew ${ }^{26}$.

Bernhard posługuje się tu terminem die Baumgrenze, który w polskich pracach naukowych tłumaczy się jako 'granica drzew'27 - czyli krawędź obszaru, w którym drzewa są zdolne do wzrostu - i różnicuje wobec terminu

${ }^{23}$ J.C. Cooper, Lexikon alter Symbole, Lipsk 1986, s. 208. Cyt. za: P. Rychło, Szibbolet. Poszukiwania tożsamości żydowskiej w niemieckojęzycznej poezji Bukowiny, przeł. A. Chłopik, P. Jarosz, Kraków-Budapeszt 2012, s. 29.

${ }^{24}$ Przykładowo w Zaburzeniu czytamy słowa syna, który podróżuje ze swoim ojcem lekarzem, towarzysząc mu podczas kolejnych odwiedzin pacjentów: „Przyrodnia siostra jest córką jego matki, z chilijskiego ojca, i mój ojciec oświecił mnie co do stosunku obojga względem siebie. Żyją ze sobą jak mąż i żona; ona, gdy tylko wpuści mojego ojca do leśniczówki i zamelduje bratu o jego przybyciu, natychmiast chowa się w swoim pokoju, a pojawia się dopiero po to, żeby ojca pożegnać". T. Bernhard, Zaburzenie, przeł. S. Lisiecka, wyd. 2, Warszawa 2013, s. 53.

${ }^{25}$ Pisze o tym A. Barełkowska: „Rękopisy pokazują, że w poszczególnych redakcjach tekstu Bernhard dowolnie manipulował tym motywem, raz pisząc o nich jak o rodzeństwie, innym razem jak o małżeństwie. W końcu zdecydował się połączyć oba pomysły, zapewne również ze względu na możliwość większego ładunku przemocy w „małżeńskim piekle Konradów" (A. Barełkowska, Kategoria teatralności..., s. 203).

${ }^{26}$ Tuż poniżej granicy drzew znajduje się też chata (Hütte) Heideggera, ukryta pomiędzy lasami i trawami, wraz z frazą Paula Celana pochodzącą z wiersza Todnauberg: „Arnika, Augentrost, der/Trunk aus dem Brunnen mit dem/Sternwürfel drauf".

Przypomina ona szwarcwaldzką zagrodę opisaną przez filozofa w Budować, mieszkać, myśleć, taką, „którą jeszcze przed dwustu laty budowało chłopskie zamieszkiwanie. Dom urządziła tu moc otwierania rzeczy dla prostoty Ziemi i Nieba, Istot Boskich i Śmiertelnych. [...] Nie zapomniała o kącie ze świętymi obrazami nad wspólnym stołem, przyznała w izbach uświęcone miejsce połogowi i «drzewu umarłych (Totenbaum)» - tak w tamtych stronach nazywają trumnę - i w ten sposób różnym porom życia wytyczyła pod jednym dachem tor ich wędrówki przez czas". M. Heidegger, Budować, mieszkać, myśleć, przeł. K. Michalski, K. Pomian, M.J. Siemek, J. Tischner, K. Wolicki, Warszawa 1977, s. 332.

${ }^{27}$ Marian Sokołowski, na podstawie dzieła Brockmanna-Jeroscha pt. Baumgrenze und Klimacharakter, pisze o trzech rodzajach granic drzew: alpejskiej (w górach), arktycznej i antarktycznej (w pobliżu biegunów) oraz kontynentalnej (wewnątrz lądów). Zaznacza też, iż granica drzew jest ważniejsza dla geobotanika niż granica lasu, ponieważ tę drugą trudniej wyznaczyć, a także „jest ona bardziej od granicy drzew narażona na sztuczne obniżenie przez wyręby i wypas". M. Sokołowski, Nowsze badania nad wptywem charakteru klimatu 
'granica lasu' (die Waldgrenze), rozumianego jako ta linia, którą można rozciągnąć wzdłuż górnej krawędzi zwartego lasu. Pomiędzy granicą lasu a granicą drzew występują jedynie pojedyncze drzewa. Granica wyznaczająca możliwość życia drzew może przybierać postać wyraźnej, radykalnej linii lub stopniowego przechodzenia od wysokich drzew do tych skarlałych, płożących się, zakrzywionych (w niemieckim das Krummholz, które może oznaczać również kosodrzewinę), a powyżej krzewów i traw.

Baumgrenze to zatem granica istnienia i nieistnienia ${ }^{28}$. Wystarczy się odwrócić, żeby zobaczyć ten drugi obszar. Dla pisarstwa autora Wymazywania charakterystyczne jest balansowanie na różnych granicach - życia i śmierci, komedii i tragedii (komizmu i tragizmu), a także na granicach stricte przestrzennych. Granica wpisuje się także w Bernhardową dwukierunkowość czy wymienność, jest zarówno tym, co łączy, jak i tym, co oddziela ${ }^{29}$. Można przyjąć, iż większość opisywanych przez austriackiego pisarza zdarzeń jest sytuacjami (doświadczeniami) granicznymi ${ }^{30}$ (także dosłownie), doprowadzonymi ad extremum (na przykład choroba lub relacja kazirodcza). Dochodzenie do granic możliwości przyjmuje jednak różne realizacje. Bohaterowie Bernharda często sięgają górnej bądź dolnej granicy obłędu, doprowadzają go do ostateczności lub zatrzymują się tuż przed. Granica ta jest często samobójstwem i niejednokrotnie ma miejsce w lesie (na przykład prześwit w Korekcie).

Charakterystyczne jest też bezgraniczne oddanie się pracy umysłowej. Intelektualne projekty bohaterów Bernharda najczęściej związane są z człowiekiem lub jego wybranymi własnościami. Wyjątek stanowi jednak narrator wczesnego opowiadania pt. Czapka, który zajmuje się leśnictwem, jakby las lub drzewo były jedną z tych właściwości lub przynajmniej znacząco towarzyszyły umysłowi człowieka. Brak umiaru i przesada, świadczące jednocześnie o sile i słabości bohaterów, o ich tragedii i komedii, są również obecne na poziomie językowo-formalnym. Zarówno bohaterowie Bernharda, jak i słowa, za pomocą których wypowiadają swoje tyrady, doświadczają pogranicza rozumu i szaleństwa.

na zasiagi drzew, „Sylwan. Organ Małopolskiego Towarzystwa Leśnego i Spółdzielni Leśników" 1923, nr 2, s. 25-36.

${ }^{28} \mathrm{~W}$ opowiadaniu Bernharda drzewo na granicy jest drzewem życia i śmierci, podobnie jak to pierwsze, również podwójnie wartościowane, drzewo poznania dobrego i złego. Samo, będąc obok dwóch granicznych stanów, towarzyszy w nich także człowiekowi, jako drzewo, ale i drewno przedmiotów codziennego użytku, także tych pierwszych i ostatnich, w których leży człowiek.

${ }^{29}$ Bernhard Welte, fryburski filozof religii, tak pisze o granicy: „W niej to, co pozytywne, jest równocześnie negatywne, a to, co negatywne, zarazem pozytywne, to, co w niej dzielące, jest jednocześnie łączące, a to, co łączące, zarazem dzielące; jej discretum jest zarazem continuum, a jej continuum jednocześnie discretum". B. Welte, Die Grenze als göttliches Geheimnis, [w:] tegoż, Zur Frage nach Gott. Gesammelte Schrifften III/3, Fryburg Bryzgowijski-Bazylea-Wiedeń 2008, s. 17. Cyt. za: J. Piecuch, Fenomenologia doświadczenia granicznego w ujęciu Józefa Tischnera, "Argument” 2011, nr 2, s. 239-258, tu: 253.

J. Leociak, Doświadczenia graniczne. Studia o dwudziestowiecznych formach reprezentacji, Warszawa 2009. 
Zatrzymajmy się jednak na dłużej przy rycinach Lehmdena znajdujących się $\mathrm{w}$ tej książce. Jest to bowiem jedyny przypadek połączenia przez Bernharda tekstu $\mathrm{z}$ obrazem, mimo iż $\mathrm{w}$ samych stworzonych przez niego narracjach pojawiają się dzieła malarskie ${ }^{31}$. Jak pisze Raimund Fellinge, ilustracje zamieszczone w An der Baumgrenze nie powstały specjalnie na potrzeby tego tomu - wszystkie pochodzą z lat pięćdziesiątych. Umieszczone są w książce w miarę równomiernie i zgodnie z długością poszczególnych opowiadań - sześć obok Der Kulterer i po trzy dla Der Italiener. Fragment oraz An der Baumgrenze.

Anton Lehmden urodził się 2 stycznia 1929 roku w Nitrze jako syn ogrodnika. Dzieciństwo spędził na wsi, której sceneria silnie wpłynęła na wyobraźnię oraz wrażliwość przyszłego malarza i grafika, a także pozostawiła stałe odbicie w całej jego twórczości. Szeroko pojmowany krajobraz jest bowiem głównym tematem prac słowacko-austriackiego artysty. Walter Koschatzky w swoim tekście poprzedzającym katalog dzieł Lehmdena przywołuje jego słowa o pewnej właściwości świata: „Wenn man ein paarmal

${ }^{31}$ Najbardziej wyrazistym przykładem jest powieść pt. Dawni mistrzowie. Komedia, na podstawie której powstał, wydany w 2011 roku przez Suhrkamp Verlag, komiks Nicolasa Mahlera, austriackiego rysownika, jednego z najważniejszych twórców współczesnego europejskiego komiksu alternatywnego. Istnieją też jednak inne, drobniejsze, lecz z pewnością nie mniej ważne przykłady obecności sztuki w tekstach Bernharda. W Kalkwerk Konrad, pozbywszy się prawie wszystkich rzeczy godnych sprzedania, zachowuje jedynie obraz Francisa Bacona: „Francisa Bacona nie sprzedam, Francisa Bacona nie sprzedam, Francisa Bacona nie sprzedam. A kiedy przyjdą ludzie z banku, schowam go. Schowam Francisa Bacona. Muszę go schować, nieustannie myślał Konrad" (T. Bernhard, Korekta, s. 47).

Twórczość Bacona była szczególnie ważna dla Bernharda i jego tekstów. Jak wspomina Hans Höller w książce Der unbekannte Thomas Bernhard (Mattighofen 2014), w latach osiemdziesiątych w Londynie, Wieland Schmied - austriacki historyk sztuki, pisarz i literaturoznawca - zapytał malarza w imieniu Bernharda, czy nie przygotowałby ilustracji do zbioru opowiadań. Niestety, Bacon nie przyjął tej propozycji, nie chcąc angażować się w nowe książki (s. 26). O artystycznym i myślowym pokrewieństwie Francisa Bacona i Thomasa Bernharda wspominał Dariusz Czaja w końcowym fragmencie tekstu Francis Bacon: ślady katastrofy: „Tak, to najprawdziwsza prawda, sztuka Bacona pogrążona jest w ciemnościach. Bo też, jak każda wielka sztuka, o ciemnościach w nas i wokół nas mówi. Teza, że w ciemnościach niczego nie widać, jest zapewne prawdą, ale tylko w dziedzinie optyki. Sztuka Bacona upewnia o czymś całkowicie przeciwnym. «Dlaczego ciemność? Dlaczego wciąż ta sama całkowita ciemność w moich książkach?» - pyta znakomity pisarz austriacki Thomas Bernhard, jeden z tych, których sztukę można rozumieć jako przenikliwy detektor wielokształtnego zła skrywającego się pod codziennymi maskami. I sobie odpowiada: «W ciemności wszystko staje się wyraźne». I to jest wyjątkowo jasna odpowiedź". D. Czaja, Francis Bacon: ślady katastrofy, „Konteksty” 2007, nr 3-4, s. 153-162, tu: 161.

Słowa Bernharda, które przywołuje Dariusz Czaja, zostają co prawda wypowiedziane przez pisarza $\mathrm{w}$ innym kontekście (jako opis zaciemnionej przestrzeni teatralnej - kart książek - z której wyłaniają się rozjaśniające słowa) i pochodzą z narracji Drei Tage, filmowego portretu pisarza, który zrealizował w 1970 roku Ferry Radax, mimo to niezwykle cenna jest uwaga o artystycznym i myślowym pokrewieństwie tych dwóch wielkich twórców XX wieku (T. Bernhard, Trzy dni, przeł. A. Wołkowicz, "Literatura na Świecie” 1997, nr 1-2, s. 237). Wspomniany film został nakręcony w jednym z prywatnych ogrodów w Hamburgu, a jego najczęstszy kadr obejmuje - pod różnymi kątami - pisarza siedzącego na białej ławce oraz potężne drzewo. 
eine Wiese gründlich besichtigt, weiß man schon Bescheid” („Kiedy kilkukrotnie poobserwuje się dokładnie łąkę, wie się już wszystko"). Ta cząstka świata (das Weltenstück ${ }^{32}$ ) mieści w sobie całość.

Wczesne prace Antona Lehmdena nawiązują do chińskiego malarstwa pejzażowego o mistycznych i taoistycznych korzeniach. Idylla kończy się jednak wraz z niemiecką inwazją na Czechosłowację w 1938 roku. Od 1945 roku Lehmden mieszka w Wiedniu, gdzie studiuje na Akademii Sztuk Pięknych pod kierunkiem Alberta Parisa Gütersloha ${ }^{33}$, duchowego ojca Wiedeńskiej Szkoły Realizmu Fantastycznego. W akademii oraz muzeum bada twórczość dawnych mistrzów, takich jak Pieter Bruegel, Joachim Patinir czy Albrecht Altdorfer ${ }^{34}$, co znajduje odbicie w kształtowaniu się jego techniki.

Traumatyczne przeżycia wojenne stają się jednym z głównych tematów jego twórczości (obok zainteresowania architekturą monumentalną i obrazów katastrof naturalnych). Pierwotne poruszanie się wokół lirycznego momentu krajobrazu zastępuje pęknięcie, zachwianie równowagi, zaburzenie. Lehmdenowskie okropności wojny ${ }^{35}$ przyjmują formę świata po trzęsieniu ziemi, a kolejne wariacje na temat rozszczepionej przestrzeni tworzą spójną wizję, opartą na mitologizacji krajobrazu. Parafrazując zdanie Gadamera na temat mowy poetyckiej, można powiedzieć, iż Lehmdenowskie krajobrazy są mitem, ponieważ uwierzytelniają się wyłącznie przez akt ich tworzenia na materiale oraz odtwarzania (w odbiorcy) w momencie patrzenia na nie ${ }^{36}$. Elementy, z którymi pracuje Lehmden, to między innymi drzewa, ptaki, owady, oderwane, spadające fragmenty ziemi, ale też monumentalna architektura - wszystkie poddane metamorfozom. To nie symbolika jednak, lecz sposób widzenia oka, które patrzyło najpierw na idylliczną naturę dziecięcych okolic, a później na krajobraz wojny. Pozornie neutralna przestrzeń mówi idiomem obserwacji i odczuwania jej przez artystę. Mimo iż krajobraz przefiltrowany jest tu w sposób szczególny przez spojrzenie malarza i nie stanowi próby wiernego oddania rzeczywistych miejsc, to Lehmden zdaje się być niezwykle lojalny wobec rzeczywistości.

Lehmdenowska opowieść, która towarzyszy prozie Bernharda, zdaje się rozpoczynać baśniowym incipitem „za górami, za lasami”, pozornie

32 Pierwszy opublikowany wiersz Thomasa Bernharda nosi tytuł Mein Weltenstück (który mieści w sobie zarówno fragment, cząstkę, jak i sztukę teatralną czy utwór muzyczny) i ukazał się 22 kwietnia 1952 roku w gazecie codziennej „Münchener Merkur”. Ten wiosenny liryk jest opisem codziennego widoku za oknem, który otwiera okwiecona jabłoń.

${ }^{33}$ Polskiemu czytelnikowi znany jest on również jako autor takich książek, jak: Stońce i księżyc. Powieść historyczna z teraźniejszości, Opowieść o Erosie oraz Kain i Abel. Legenda.

${ }^{34}$ Jeden z głównych przedstawicieli tzw. szkoły naddunajskiej.

${ }^{35}$ Por. cykl rycin Francisca Goi pt. Okropności wojny, ukończony w 1820 roku, a wydany po śmierci artysty.

${ }^{36}$ „MMowa poetycka jest zawsze mitem, to znaczy uwierzytelnia się wyłącznie przez to, że jest wypowiadana. Opowiada albo mówi o czynach i wydarzeniach i znajduje wiarę - a znajduje ją tylko o tyle, o ile w tych czynach i namiętnościach bogów czy herosów spotykamy się sami ze sobą". H.G. Gadamer, Mitopoetyckie odwrócenie w "Elegiach Duinejskich" Rilkego, [w:] tegoż, Rozum, słowo, dzieje, przeł. M. Łukasiewicz, Warszawa 2000, s. 269. 
tylko spokojnym. O specyfice jego lasów tak pisze Walter Koschatzky: „Wie drohend aber diese anscheinend idyllissche Natur ist, zeigen auch die Zeichnungen geheimnisvoller Einblicke in eigenartig zottig verschlungene Wälder und die vibrierende Verschlingung der Federstriche vermittelt deutlich die Erregung vor dieser $W_{e l t}{ }^{\prime \prime 37}$. Lehmden pokazuje, jak przerażające rzeczy mogą dziać się w pięknym otoczeniu pozornej arkadii. Thomas Bernhard także zauważał ambiwalencję natury, opisywał piękno przyrody rodzimych gór oraz lasów, ale i jednoczesną niemożność życia wśród nich i tego, co kryją.

Lehmdenowskie trivium na granicy drzew rozpoczyna rycina przedstawiająca elementy krajobrazu wyrzucone w (kosmiczną) przestrzeń. Jest w niej zarówno geometria Dürera ${ }^{38}$, jak i Walserowskie motto. Widoczne elementy zdają się poruszać, obracać wokół własnej osi, napędzać wzajemnie swój ruch. Jakby właśnie miał miejsce proces formowania świata. Albo rozpadu - czasami przecież te dwa są do siebie łudząco podobne. Elementy natury zawieszone $\mathrm{w}$ przestrzeni przypominają obraz rozwianego dmuchawca - leśny kosmos stworzony jest bowiem z Lehmdenowską subtelnością i dbałością o szczegóły, na wzór techniki filigranu ${ }^{39}$. Kontemplacyjna prostota, a także lekkość ruchu dłoni sprawiają, iż struktura tych krajobrazów jest delikatna i czuła, i mimo wielości detali pozostawia miejsce dla światła. Jego świat jest magiczny w taki sposób, w jaki widzenie dziecka i zwierzęcia jest najczystsze i najbliższe temu, na co lub na kogo patrzą.

Jak przytacza Koschatzky: „Die Erde «aktiver Mitspieler ist. Sie spaltet sich, explodiert vulkanartig, stößt Teile aus, sie speit Erdschollen in die Lüfte, sie gebiert Landstücke, Ableger, sie entläßt sie in den Raum»"40. W twórczości Lehmdena wariacje na ten temat rozpoczyna rycina o tytule Aufbrechender Berg (1956), czyli pęknięta góra, zamykająca u Bernharda opowiadanie An der Baumgrenze oraz cały tom. Otwarta powierzchnia ukazuje swoją tkankę, tworząc $w$ ten sposób poetycką geomorfologię, pamiętając, że aufbrechen to także ‘wyruszać $\mathrm{w}$ drogę'. Bezpośrednią kontynuację tematu rozpadu ziemi i przemieszczania się jej fragmentów stanowią w pracach austriackiego malarza i grafika jego dwa kolejne sztychy: Krater oraz Landschaft mit zwei schwebenden Landstücken. Takie pęknięte krajobrazy Lehmden rozwinie w swojej późniejszej

${ }^{37}$ A. Lehmden, Die Graphik. Text von Walter Koschatzky. Oeuvrekatalog der Druckgraphik: Sigrun Stock, Salzburg 1970, s. 21. „Jak groźna jest jednak ta pozornie idylliczna natura, pokazują też rysunki tajemniczego wejrzenia $w$ osobliwie krzaczasto kręte lasy $\mathrm{i}$ wibrujące splątanie pociągnięć pióra, które dokładnie przekazuje poruszenie światem" (tłum. K.S.).

${ }^{38}$ Zob. romboid z Melancholia I (1514), o którym piszą m.in. autorzy tomu Saturn i melancholia (R. Klibansky, E. Panofsky, F. Saxl, Saturn i Melancholia. Studia z historii, filozofii, przyrody, medycyny, religii oraz sztuki, przeł. A. Kryczyńska, Kraków 2009, s. 429-431), a także wstępny szkic wielościanu z tego samego roku (tamże, s. 50).

${ }^{39}$ Filigran to "technika zdobnicza wchodząca w zakres złotnictwa; polega na wykonywaniu ornamentu lub całego przedmiotu z bardzo cienkich drucików złotych lub srebrnych", które tworzą delikatny wzór ażurowy. Stownik terminologiczny sztuk pięknych, red. K. Kubalska-Sulkiewicz, M. Bielska-Łach, A. Manteuffel-Szarota, wyd. 5, Warszawa 2007, s. 113.

${ }^{40}$ A. Lehmden, Die Graphik..., s. 22. „Ziemia jest aktywnym zawodnikiem. Rozpada się, wulkanicznie eksploduje, wyrzuca z siebie fragmenty, wybucha grudami ziemi w powietrze, rodzi kawałki terenu, odgałęzienia, uwalnia się w przestrzeni" (tłum. K.S.). 
twórczości w wyobrażenia katastrof naturalnych. W tekstach Bernharda również pojawia się ów mechanizm drążenia - na przykład w charakterystyce pracy kołatków i korników opisanej w Korekcie oraz dramacie Na polowaniu - bądź też opis miejsc jemu pokrewnych, czyli wąwozów.

Na rycinie przedstawiającej rozszczepioną górę drzewa są, jak zawsze u Lehmdena, smukłe i wysokie, co odpowiada przejrzystości jego obrazów, a rosną aż do samego szczytu - ich granicą jest wierzchołek wzniesienia, najczęściej znajdujący się tuż pod otwartą przestrzenią nieba - choć temu zaprzecza inny tekst Bernharda, Mróz, w którym czytamy:

Góry, widzi pan, są wielkimi świadkami wielkich bólów - powiedział malarz. Ruszył w stronę góry. - Ludzie mówią zawsze: góra graniczy z niebem. Nigdy nie mówią: góra graniczy z piekłem. Dlaczego? - Powiedział: - Wszystko jest piekłem. Niebo i ziemia, ziemia i niebo są piekłem. Rozumie pan? Nad sobą i pod sobą mamy tu piekło! Ale z natury rzeczy nic nie graniczy z niczym. Rozumie pan? Nie ma żadnej granicy. - Wiatr halny, który wtargnął nagle, pozwalał dojrzeć niedostrzegalne zazwyczaj szczegóły po cienistej stronie. - Widzi pan - powiedział malarz - że wszystko to tylko cienie? O, kozice! Widzi pan! - Pociągnął mnie ku sobie. - Widzi pan! - powiedział. Ale ja nic nie widziałem. - Ta góra od dawien dawna kojarzy mi się z olbrzymim katafalkiem. Widzi pan! - Faktycznie góra ma kontury olbrzymiego katafalku ${ }^{41}$.

U Lehmdena istnieje (przynajmniej optycznie) także inna granica - wyznaczona przez pęknięcie - granica wewnętrzna, która oddziela to, co powinno być całością, ukazując strukturę ziemi. Pęknięte góry w pracach Lehmdena stają się jeszcze bardziej niepokojące, gdy pamięta się o jego fascynacji chińskim malarstwem pejzażowym, w którym góra odgrywa szczególną rolę jako miejsce święte, dom nieśmiertelnych dusz. O jej znaczeniu mówi też samo chińskie wyrażenie oznaczające krajobraz, które składa się z dwóch znaków - shān, czyli góra, i shuǐ, woda - będące również nazwą malarstwa pejzażowego oraz stylu w poezji koncentrującego się na naturze.

Przestrzeń zostaje $\mathrm{w}$ pracach Lehmdena przekształcona przez myśli i doświadczenia artysty, tworząc niepowtarzalny poetycki świat. To zapis rozważań o krajobrazie i wszystkim tym, co jest w niego wpisane. Myślowe metamorfozy powierzchni.

Powróćmy do kilku zdań przed epigraficznym początkiem. Tekst Walsera brzmi wtedy:

${ }^{41}$ T. Bernhard, Mróz, s. 150-151. 
Nun wurde mir mit einem Mal alles zu Traum, Liebe und Phantasie. Alles, was ich jetzt anschaute, nahm große und hohe Form an. Die Gegend selber schien zu dichten, zu phantasieren. Sie schien über ihrer eigenen Schönheit zu träumen. Das Land war wie versunken in ein tiefes, musikalisches Denken ${ }^{42}$.

Ziemia, która fantazjuje i pogrąża się w muzycznym myśleniu - to być może słowa najbliższe Lehmdenowskim Weltlandschaften, ale też kontrapunkt dla tekstu Bernharda, który tworzy wraz z nim coś na kształt fantastycznego realizmu.

Przyjrzenie się drzewno-leśnym zdaniom Bernharda wielokierunkowo poszerza konteksty badawcze twórczości tego pisarza, co obrazują chociażby dwa ostatnie wydane po polsku tomy prozatorskie: Tak. Wyjadacze (2015) oraz Chodzenie. Amras (2017) ${ }^{43}$. Najbardziej znaną jest jednak fraza: „las, wysokopienny las, wycinka", której jedno z możliwych znaczeń włączyć można do najbardziej zbadanego (w pracach niemieckojęzycznych ${ }^{44}$ ) tematu leśnego w twórczości Thomasa Bernharda - postaci drwala ${ }^{45}$ (niemieckie der Holzfäller - 'drwal', i das Holzfällen - 'wycinka'). Autor Wycinki pisze też często o innych, użytych tym razem w dosłownym znaczeniu, formach zanikania lasu. Ciekawym zabiegiem w kontekście jednego z najważniejszych Bernhardowskich pojęć - wymazywania, które Katarzyna Kuczyńska-Koschany nazywa „eufemizmem-matką" wszystkich "czarnych eufemizmów"46 - jest bliska lektura dramatu Na polowaniu oraz Korekty: w pierwszym utworze wycięty musi zostać las zaatakowany przez korniki, a w drugim - pokrewne im kołatki nadjadają dom głównego bohatera, Altensam. W utworach Bernharda pojawiają

${ }^{42}$ "Naraz wszystko stało się dla mnie snem, miłością i fantazją. Wszystko, na co teraz patrzyłem, przybierało wielkie i podniosłe formy. Sama okolica zdawała się tworzyć i fantazjować. Zdawała się śnić o własnej piękności. Jakby się pograła w głębokiej, śpiewnej zadumie". R. Walser, Spacer (I), s. 141.

Przytaczam tekst $w$ jego brzmieniu niemieckim również ze względu na to, że tłumaczenie polskie $w$ niektórych punktach rozmija się z oryginałem.

${ }^{43} \mathrm{~W}$ Amras również pojawia się granica drzew (w polskim tłumaczeniu ponownie "granica lasów"; T. Bernhard, Chodzenie. Amras, przeł. S. Lisiecka, Łódź 2017, s. 180) zestawiona ze śmiercią stada uduszonych pod lawiną saren, a także wielokrotne mówienie o drodze w górę, do modrzewi.

${ }^{44}$ Zob. np. A. Pfabigan, Holzfällen. Männliche Homosexualität als Thema der Bernhardschen Prosa, [w:] Die Musik, das Leben und der Irrtum. Thomas Bernhard und die Musik, red. O. Kolleritsch, Wiedeń, Graz 2000, s. 169-189; E. Nickel, Flaneur. Die Ermöglichung der Lebenskunst in Thomas Bernhards später Prosa, Heidelberg 1997; N. Langendorf, Schimpfkunst. die Bestimmung des Schreibens in Thomas Bernhards Prosawerk, Frankfurt nad Menem 2001.

${ }^{45}$ Wspominała o tym również Monika Muskała w rozmowie z grudnia 2015 roku dla "Dwutygodnika”, tłumacząc wybór słowa „wycinka” w przekładzie tytułu tego utworu; http://www.dwutygodnik.com/artykul/6281-na-poczatku-lutego-dokladnie-siedemnastego. html (dostęp: 10.03.2018).

${ }^{46}$ K. Kuczyńska-Koschany, „Bсе поэты жиды”. Antytotalitarne gesty poetyckie i kreacyjne wobec Zagłady oraz innych doświadczeń granicznych, Poznań 2013, s. 35-37. 
się również leśnicy i myśliwy, a także samo polowanie, obecne nie tylko we wspomnianym dramacie i podniesione przez pisarza, w jednym $\mathrm{z}$ listów, do rangi określenia opisującego pewne okresy $\mathrm{w}$ historii ${ }^{47}$.

W kolejnych tekstach powraca triada: las - chodzenie - myślenie/mówienie. Bernhard kilkukrotnie w swoich utworach tworzy też pary leśnych spacerowiczów - są to między innymi opowiadanie Tak oraz wczesna krótka proza pt. Attaché ambasady francuskiej ${ }^{48}$, którą można uznać za prototypową wobec niego. W utworze tym obecna jest inna leśna granica - Bernhard pisze o spotkaniu „,w lesie, w sektorze lasu mieszanego, graniczącym z lasem świerkowym" ${ }^{49}$. Na granicy wewnętrznej, w miejscu, w którym spotykają się dwa rodzaje lasów, wujek narratora, leśniczy, niespodziewanie spotyka przystojnego i dobrze ubranego młodego mężczyznę. Spotkanie to natychmiast odbiera jako szczęśliwy przypadek, chociaż nieznajomego może w pierwszej chwili określić jedynie na podstawie głosu, ponieważ ciemność nie pozwala na zobaczenie jego twarzy. Podobnie jak język Persjanki z Tak, „niemczyzna młodego mężczyzny była nadzwyczajna, choć jednak wypowiadana przez obcokrajowca" ${ }^{50}$ i tym razem również to Inny staje się bliskim, „«jednym z najistotniejszych ludzi» w jego życiu" ${ }^{51}$.

Analogicznie do leśnej rozmowy w Tak, tutaj także myślenie i mówienie posiada kolejne - odmienne, lecz nakładające się na siebie - warstwy tematyczne. Pierwsza myśl wiąże się z rozróżnieniem lasów na ten, który jest "dobry”, i ten, który jest "zły". Ciemność oraz bliskość granicy sprawiają jednak, że trudno z całą pewnością stwierdzić, gdzie właśnie znajdują się bohaterowie - szczególnie, iż te leśne są zazwyczaj płynne, roślinność jednego drzewostanu wdziera się bowiem w obszar tego drugiego, a już sam las mieszany ma w sobie część lasu iglastego. Punkt wyjścia, w którym wydarza się spotkanie, jest jednak znany.

Temat „leśnictwa i gospodarki leśnej” 52 płynnie przechodzi w dziedzinę filozofii. Kolejne wątki rozmowy dotyczą literatury i muzyki, a - jak wspomina leśniczy - „kiedy już opowiedziałem młodemu mężczyźnie o nawożeniu i ciemnej porębie, o rodzajach drewna uzyskanego z drzew

${ }^{47}$ Tak pisał Bernhard w liście do Unselda z 15 grudnia 1972 roku, tłumacząc tytuł powstającej właśnie sztuki: „unsere (und nicht nur unsere) Zeit, Epoche etcetera, ist eine einzige Jagdgesellschaft" (T. Bernhard, S. Unseld, Der Briefwechsel, s. 337). Niemieckie słowo die Jagdgesellschaft oznacza zarówno polowanie, wraz z wszystkimi wydarzeniami bezpośrednio z nim związanymi, jak i samych uczestników, grupę myśliwych, lub też szerzej - kategorię towarzystwa łowieckiego, która w tym kontekście może stanowić eufemizm nazizmu lub innych ideologii o charakterze totalitarnym. Myślenie Bernharda wydaje się w tym miejscu szczególnie bliskiego temu, które zawarł w eseju Masa i władza Elias Canetti.

${ }^{48}$ Przywołuję tu jedynie wybrane wątki interpretacyjne związane $\mathrm{z}$ lasem lub drzewami obecnymi $w$ tym utworze, skupiając się przede wszystkim na znaczeniu granicy oraz pokrewieństwa wybranej przez pisarza przestrzeni z myślami bohaterów.

${ }^{49}$ T. Bernhard, Attaché ambasady francuskiej. Dziennik wakacyjny, zakończenie, przeł. E. Dyczek, M.F. Nowak, „Odra” 2004, nr 7-8, s. 65.

\footnotetext{
${ }^{50}$ Tamże, s. 66.

${ }^{51}$ Tamże, s. 67.

${ }^{52}$ Tamże, s. 66.
} 
rosnących w cieniu, bardzo interesującą historię o wejmutce, zeszliśmy na rozmowę o polityce" ${ }^{53}$. Wszystkie jednak związane są z przestrzenią, po której poruszają się bohaterowie, przestrzenią ciemnego austriackiego lasu, który posiada dwie strony - dobrą i złą. Chodzenie po określonym terenie jest też myślowym przemieszaniem się po nim:

Moje rewiry [Grundstücke] są moimi tematami. Mogę sobie wyobrazić, iż filozof dzień i noc widzi swoje filozofie, tak też moja sztuka polega na tym, aby wciąż przenikać wszystkie rewiry. Muszę wiedzieć, czy i z jakiej przyczyny drzewo jest spróchniałe. Muszę wiedzieć, co jest w drzewie. Zawsze muszę wiedzieć, cokolwiek to jest ${ }^{54}$.

Całkowita znajomość lasu polega zarówno na jego szerokim oglądzie, jak i badaniu poszczególnych drzew, nawet jeśli ta wiedza okaże się niepokojąca, lub wręcz - przerażająca, jak dzieje się w przypadku odkrycia kornika w całym lesie $\mathrm{z}$ dramatu $\mathrm{Na}$ polowaniu. Na to, czym jest przemyśliwanie miejsc obecnych w tekstach Bernharda, wskazują też wyrażenia typu: „wszystko, co rozumiem przez Wolfsegg, i wszystko, czym jest Wolfsegg" ${ }^{\prime 5}$, zawarte także w tytule manuskryptu Roithamera: „O Altensam i wszystkim, co ma związek z Altensam, ze szczególnym uwzględnieniem Stożka" ${ }^{\prime 6}$.

Las lub pojedyncze drzewa tworzą często, w utworach Bernharda, przestrzeń, w której dzieją się opisywane wydarzenia czy - mówiąc dokładniej - w której wybrzmiewają długie monologi, co przy minimalizmie w przedstawianiu krajobrazu jest szczególnie dostrzegalne. Miejsca, w których poruszają się, myślą lub mówią bohaterowie, skonfrontowane są z ich kondycją, współdzielą doświadczenie stanu, w jakim znajduje się mówiący. Funkcjonują przy tym tak jak dzieło sztuki, odnosząc się do zintensyfikowanego poczucia podmiotowości, i wpływają na wzrok przenoszony z takiej przestrzeni na inną. Przebywanie w jednej z nich, odczuwanie jej i oglądanie nie pozostaje bez wpływu na kolejne konfrontacje z rzeczywistością. Podobnie jak przy spotkaniu z dziełem sztuki miejsca te uczestniczą w rozmowie, konstruują twórczą relację podmiot - podmiot. Bernhard mówiący o sztuce i Bernhard mówiący o naturze niewiele się od siebie różnią. Świat zewnętrzny działa bowiem u niego dopiero, gdy spotka się z osobnym spojrzeniem obserwatora i gdy to postrzeganie konkretnego obiektu czy miejsca wpłynie na kolejne spotkania "pomiędzy”.

\footnotetext{
${ }^{53}$ Tamże.

54 Tamże, s. 67.

${ }^{55}$ T. Bernhard, Wymazywanie. Rozpad, przeł. S. Lisiecka, wyd. 2, Warszawa 2010, s. 165.

${ }^{56}$ T. Bernhard, Korekta, przeł. M. Kędzierski, Warszawa 2013, s. 7.
} 


\section{BI B LIOGR A F I A}

Albes C., Der Spaziergang als Erzählmodell. Studien zu Jean-Jacques Rousseau, Adalbert Stifter, Robert Walser und Thomas Bernhard, Túbingen, Bazylea 1999.

Bauer Z., Wędrować, żeglować, wertować: o pewnych wspótczesnych metaforach podróży, "Annales Universitatis Paedagogicae Cracoviensis. Studia Historicolitteraria" 2007, nr 7, s. 35-44.

Bernhard T., Attaché ambasady francuskiej. Dziennik wakacyjny, zakończenie, przeł. E. Dyczek, M.F. Nowak, „Odra” 2004, nr 7-8, s. 65-67.

Bernhard T., Chodzenie. Amras, przeł. S. Lisiecka, Łódź 2017.

Bernhard T., Korekta, przeł. M. Kędzierski, Warszawa 2013.

Bernhard T., Moje nagrody, przeł. M. Kędzierski, Warszawa 2010.

Bernhard T., Mróz, przeł. S. Błaut, posł. H. Orłowski, Poznań 1979.

Bernhard T., Na granicy lasów, przeł. S. Lisiecka, [w:] Czyż jest piękniejszy kraj... Opowiadania austriackie, oprac. S.H. Kaszyński, Warszawa 1980, s. 168-178.

Bernhard T., Spotkanie. Rozmowy z Krista Fleischmann, przeł. S. Lisiecka, Warszawa 2010.

Bernhard T., Trzy dni, przeł. A. Wołkowicz, „Literatura na Świecie” 1997, nr 1-2, s. 233-243.

Bernhard T., Unseld S., Der Briefwechsel, Frankfurt nad Menem 2011.

Bernhard T., Wycinka. Ekscytacja, przeł. M. Muskała, Warszawa 2011.

Bernhard T., Wymazywanie. Rozpad, przeł. S. Lisiecka, wyd. 2, Warszawa 2010.

Bernhard T., Zaburzenie, przeł. S. Lisiecka, wyd. 2, Warszawa 2013.

Cooper J.C., Lexikon alter Symbole, Lipsk 1986.

Czaja D., Francis Bacon: ślady katastrofy, „Konteksty” 2007, nr 3-4, s. 153-162.

Die Ursache bin ich selbst, Madryt 1986.

Fellinger R., Der herzliche Thomas Bernhard, [online] http:/ / diepresse.com/ home/spectrum/zeichenderzeit/565184/print.do (dostęp: 10.03.2018).

Gadamer H.G., Mitopoetyckie odwrócenie w "Elegiach Duinejskich" Rilkego, [w:] H.G. Gadamer, Rozum, słowo, dzieje, przeł. M. Łukasiewicz, Warszawa 2000.

Grodecka A., Fotografie nieistniejacego świata. O polskiej sztuce fantastycznej, „Poznańskie Studia Polonistyczne. Seria Literacka”, nr 28 (48), s. 62.

Heidegger M., Budować, mieszkać, myśleć, przeł. K. Michalski, K. Pomian, M.J. Siemek, J. Tischner, K. Wolicki, Warszawa 1977.

Höller H., Der unbekannte Thomas Bernhard, Mattighofen 2014.

http://www.suhrkamp.de/insel-verlag/verlagsgeschichte_71.html (dostęp: 10.03.2018).

Jaspers K., Sytuacje graniczne, przeł. M. Skwieciński, [w:] R. Rudziński, Jaspers, Warszawa 1978.

Klibansky R., Panofsky E., Saxl F., Saturn i Melancholia. Studia z historii, filozofii, przyrody, medycyny, religii oraz sztuki, przeł. A. Kryczyńska, Kraków 2009.

Kuczyńska-Koschany K., „Bсе поэты жиды”. Antytotalitarne gesty poetyckie i kreacyjne wobec Zagłady oraz innych doświadczeń granicznych, Poznań 2013.

Langendorf N., Schimpfkunst. die Bestimmung des Schreibens in Thomas Bernhards Prosawerk, Frankfurt nad Menem 2001. 
Lehmden A., Die Graphik. Text von Walter Koschatzky. Oeuvrekatalog der Druckgraphik: Sigrun Stock, Salzburg 1970.

Leociak J., Doświadczenia graniczne. Studia o dwudziestowiecznych formach reprezentacji, Warszawa 2009.

Łukasiewicz M., Robert Walser, Warszawa 1990.

Madeyski J., Realizm fantastyczny, [w:] Malarze polscy XIX i XX wieku. Mata encyklopedia rynku sztuki, red. J. Rapicka, Kraków 2004, s. 188-189.

Na poczatku lutego, dokładnie siedemnastego. Rozmowa z Monika Muskata, „Dwutygodnik" 2015, nr 12, s. 174.

Nickel E., Flaneur. Die Ermöglichung der Lebenskunst in Thomas Bernhards später Prosa, Heidelberg 1997.

Pfabigan A., Holzfällen. Männliche Homosexualität als Thema der Bernhardschen Prosa, [w:] Die Musik, das Leben und der Irrtum. Thomas Bernhard und die Musik, red. O. Kolleritsch, Wieden, Graz 2000, s. 169-189.

Piecuch J., Fenomenologia doświadczenia granicznego w ujęciu Józefa Tischnera, "Argument" 2011, nr 2, s. 239-258.

Rychło P., Szibbolet. Poszukiwania tożsamości żydowskiej w niemieckojęzycznej poezji Bukowiny, przeł. A. Chłopik, P. Jarosz, Kraków-Budapeszt 2012.

Stownik terminologiczny sztuk pięknych, red. K. Kubalska-Sulkiewicz, M. Bielska-Łach, A. Manteuffel-Szarota, wyd. 5, Warszawa 2007.

Sokołowski M., Nowsze badania nad wptywem charakteru klimatu na zasiagi drzew, „Sylwan. Organ Małopolskiego Towarzystwa Leśnego i Spółdzielni Leśników" 1923, nr 2, s. 25-36.

Szulakiewicz M., Granice jako problem wspótczesnej kultury - wprowadzenie, [w:] Granice i ograniczenia. O doświadczeniu granic $i$ ich przekraczaniu, red. M. Szulakiewicz, Torun 2010, s. 7-17.

Walser R., Spacer (I), [w:] R. Walser, Maty krajobraz ze śniegiem. Małe poematy. Utwory proza. Mata proza, przel. M. Łukasiewicz, Izabelin 2003, s. 140-141.

Welte B., Die Grenze als göttliches Geheimnis, [w:] B. Welte, Zur Frage nach Gott. Gesammelte Schrifften III/3, Fryburg Bryzgowijski-Bazylea-Wiedeń 2008.

Wittchen-Barełkowska A., Kategoria teatralności w dziele Thomasa Bernharda, Poznań 2014.

\section{STRESZCZENIE}

Artykuł ma charakter interpretacyjny i stanowi próbę przyjrzenia się opowiadaniu Thomasa Bernharda pt. An der Baumgrenze (tytuł polskiego tłumaczenia brzmi Na granicy lasów) z perspektywy drzewno-leśnej oraz doświadczenia granicy, która wykracza poza swoje topograficzne znaczenie. Lasy lub pojedyncze drzewa związane są $\mathrm{w}$ twórczości austriackiego pisarza $\mathrm{z}$ umysłami bohaterów. W przestrzeni tej często dochodzą oni do granicy obłędu, tracą kontrolę nad sobą, co ostatecznie prowadzi do śmierci. Tekst koncentruje się także na rycinach Antona Lehmdena 
- przedstawiciela Wiedeńskiej Szkoły Realizmu Fantastycznego - które znajdują się w tomie zawierającym An der Baumgrenze i twórczo dopełniają narracje Bernharda.

\section{Słowa kluczowe}

Thomas Bernhard, Anton Lehmden, literatura austriacka, realizm fantastyczny, doświadczenie graniczne, las, drzewo

\section{SUMMARY}

\section{Tree Line. About Forest Boundary Experiences in the Story An der Baumgrenze of Thomas Bernhard}

The article has interpretative character, and attempts to take a deeper look into the story of Thomas Bernhard An der Baumgrenze (the title of the polish translation is Na granicy lasów) from a wood-forest perspective and a border experience which goes beyond its topographical meaning. Forests or individual trees in the austrian writer's creation are connected with characters minds. In this space they often reach the limit of madness, lose control of themselves, what ultimately leads to death. The text also focuses on the paintings of Anton Lehmden - a representative of the Vienna School of Fantastic Realism - which are included in the tome containing An der Baumgrenze and creatively complements Bernhard's narrations.

\section{Keywords}

Thomas Bernhard, Anton Lehmden, Austrian literature, fantastic realism, border experience, forest, tree 